Przegląd Badań Edukacyjnych Educational Studies Review

ISSN 1895-4308

nr 27 (2/2018), s. 71-84

ORYGINALNE ARTYKUŁY BADAWCZE

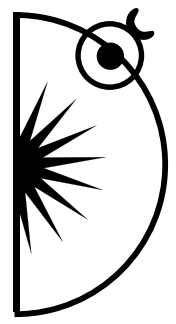

Tomasz Warchoł

ORCID iD: 0000-0002-7978-8149

University of Rzeszów; e-mail: twarchol@ur.edu.pl

\title{
A Sense of the Role and Value of Non-Formal Education in the Opinion of Students Participating in Interactive Workshops
}

http://dx.doi.org/10.12775/PBE.2018.017

\begin{abstract}
The paper presents the results that relate to the opinion of the role and value of non-formal education using interactive workshops of students taking part in a series of meetings organised by the University of Rzeszow. The main method was the diagnostic survey carried out using the CAPI technique (Computer Assisted Personal Interview). Today, it is extremely important to support the traditional formal education with its other forms. As shown in the results, students expect schools to organise non-formal education, which gives them the opportunity to develop interests that stimulate learning. Based on the presented results, we can also say that activities using interactive workshops bring very satisfactory learning outcomes, so it is worth supporting and implementing similar ways of education.
\end{abstract}

Keywords: non-formal education, interactive workshops, study on education, didactics.

\section{Introduction}

The contemporary Polish educational system is undergoing changes in the organisation of formal education, both in structural and programmatic terms. These changes are designed to provide new, better education of children and 
youth, which will be tailored to the needs of today's labour market, social and economic needs (Internet 1).

In the modified method of provision of education, we must not forget that education is a broad term, which includes such types of education as formal, non-formal and informal (Sławiński, 2014, p. 13-21).

Formal education is defined as an activity undertaken or initiated by one or more people, whose aim is to introduce changes in the knowledge, skills and attitudes of individuals, groups and communities. In this activity, the central figure is an educator - a person acting for change, who stimulates and strengthens learning, as well as designs activities aimed at inducing said change (Knowles, Holton, 2009, p. 22). In the face of current rapid technological advancements, teachers have trouble reaching out to students using traditional teaching resources found in schools, additionally having to rely on outdated forms of class organization in the education process. Given the current financial condition of schools, the latest technical solutions cannot be introduced in the teaching process.

Many authors, therefore, argue that the school must embrace other forms of external educational activities offered by institutions such as: universities, museums or science parks, with a view to developing education outside the school (Podgórski, Charzyński 2014, p. 205-219).

Therefore, the new system should look into the possibility of enriching formal education with the other two forms. This approach provides students with a great chance for fuller development in the cognitive, intellectual and social scope. Research shows that the school is not a place where we can learn everything (Falk, Dierking, 2010, p. 486). The analysed research results prove that this applies both to our country and other countries, where non-formal education is used in the educational system.

In the case of the education system functioning in Poland, it is constantly enriched by various forms of non-formal education. Extracurricular classes are increasingly organised, e.g. in science centres in Poland, which take the form of informal learning, as they are not covered by the program of education or specially organised (Warchol, 2017, p. 46-50).

Non-formal education is often carried out by universities as regular or occasional science exhibitions, workshops or children universities, which allows for using significantly upgraded teaching aids, modern technology, as well as innovative methods of education. With this form of education, students are able to, at least for a moment, move away from the material strictly defined by the core curriculum and to develop their interests. 
The development of this type of education is increasingly practiced by schools, but does it have any value for students? Does it actually provide better opportunities? Do they indeed associate it with learning? The answers to these and other questions are included in this paper, which presents the results of extensive research conducted at the Centre for Innovation and Transfer of Natural Sciences and Engineering Knowledge of the University of Rzeszów at the Laboratory of Life Long Learning.

\section{Methodological assumptions of the research}

In this study, the main objective was to determine the role and the value of non-formal education by students, implemented in the form of interactive workshops.

To carry out a detailed analysis of the main objective, three research areas were defined, along with their specific goals which concerned the following aspects:

- defining the degree of understanding of the concept of non-formal education and designating places where one can participate in this type of education as extracurricular activities,

- explaining the concept of interactive workshops as one of the forms of non-formal education,

- determining the effectiveness of non-formal education by verifying knowledge after classes.

Interactive workshops were organised for students of primary and secondary schools, whose interests included the "encryption" of information, i.e. data encoding and decoding. Registration for classes was voluntary and open to any student, and the classes structure consisted of a series of eight meetings. The main objective of the course was to familiarise students with the algorithmic methods of data coding, creating simple data encryption algorithms, as well as to acquaint with the history and function of ciphers.

This theme was completely different from the traditional content of education realised in school within such subjects as mathematics, information technology, or even computer science. It is non-formal education to support the school in topics distant from those that result from the core curriculum, and its main advantage is expanding, supplementing and systematising the material at a time when information and messages are common and easy to reach by every student. 


\section{Research results}

The study involved 225 people in the proportion of $59.6 \%$ of boys and $40.4 \%$ of girls, and, in terms of schools, the majority of the surveyed group (76.9\%) were primary school students and $20.4 \%$ were secondary school students. By the origin, the majority of the group came from rural areas (55.6\%), and the rest (44.4\%) of the group came from cities. Group characteristics in terms of age can be seen in the figure below.

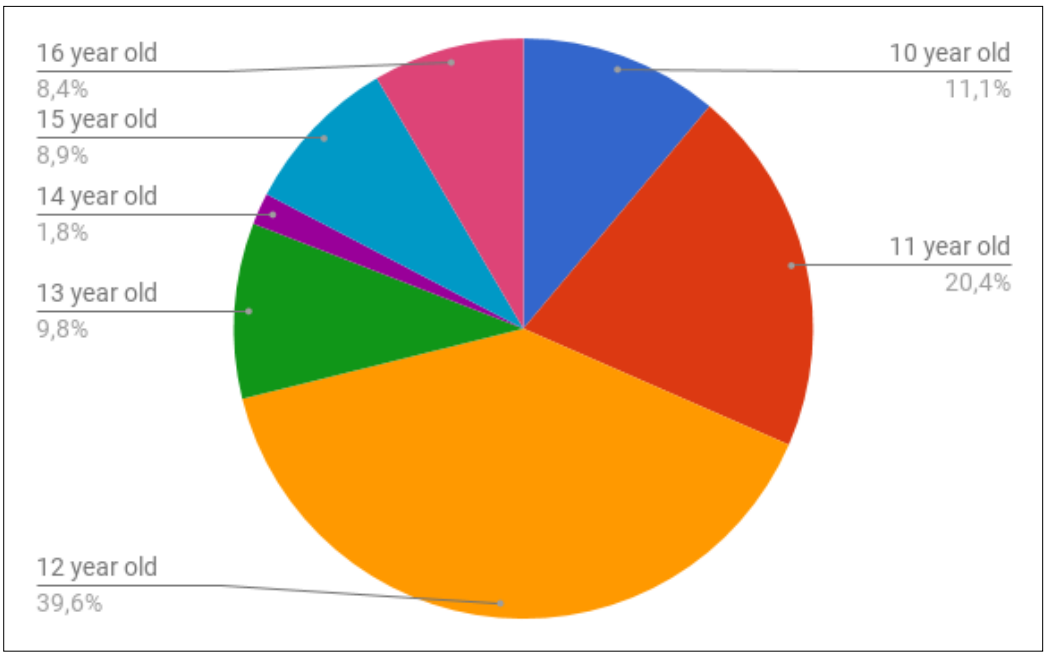

Chart 1. Studied group characteristics in terms of age

The largest part of the group were students aged 12, the second largest group were students aged 11 . The rest of the group accounted for $40 \%$. Thus, it can be concluded that the main studied sample were 5th grade students.

The first set of questions in the survey asked children to define non-formal education. Before participating in workshops, students had the opportunity to listen to a short lecture on non-formal education and the forms of its implementation. They also took part in a brief discussion in which they talked about the lecture. During the discussion, they defined non-formal education as: something nicer than a traditional class at school, learning in cool places and with a large number of new electronic equipment. Having provided this basic feedback, children moved on to active participation in classes. Based on the activities carried 
out, students gained basic knowledge about non-formal education, and they participated in one of its forms, namely interactive workshops.

In the statistical analysis of responses in the studied group, non-formal education was most frequently identified as: supplementary education - by $19.1 \%$, then classes, where we can learn something cool - by $14.7 \%$ and funby $13.8 \%$. Detailed responses were calculated based on identical or very similar responses of the students. The results also include other responses, but those did not appear often, e.g. extension or alignment of knowledge or learning through fun. Collecting all the responses and comparing them with the presented definition of non-formal education that is all activities that are aimed at broadening knowledge and gaining practical skills, but not taking place within the formally established system of education. It is learning outside of school, institution of higher education, course or training. It is based on practice, experience and student's activity (Internet 2), we can conclude that responses provided by the students support the presented definition.

In the study, students were asked to name familiar places, where non-formal education is conducted. As a result, approximately $23.6 \%$ of respondents did not know such places, while others, having the opportunity to indicate several answers, stated as follows: home - $68.1 \%$, Copernicus Science Centre in Warszawa $-25.8 \%$, library $-8.2 \%$, University of Rzeszów $-7.6 \%$. Obviously, specified items can be identified as non-formal education, assuming that the students named home as the place where they meet, e.g. with their tutors.

The students evaluated the value of non-formal education by answering the question whether, in their opinion, non-formal education classes provide the opportunity to learn new and valuable information. The results are shown based on the age of respondents.

Analysing these results, we can conclude that definitely all respondents in given age categories believe that non-formal education allows for learning something new. Only one person gave a negative answer, while 6 respondents stated that it is difficult to tell. The remaining 217 respondents, i.e. $96.9 \%$, provided a positive opinion on the question raised.

Another important element in non-formal education is the direction of changes it should follow. In the present study, we propose the following directions: practical and technical, theoretical, entertaining, organisational and social, artistic (Kupisiewicz, 2012, p. 134-154). The results of the study indicate that the most desirable direction of development is entertainment $-47.6 \%$, while the second direction is practical and technical $-32.4 \%$. Then, the sequence is as follows: artistic $-8 \%$, theoretical $-6.2 \%$, organisational and social $-5.8 \%$. 


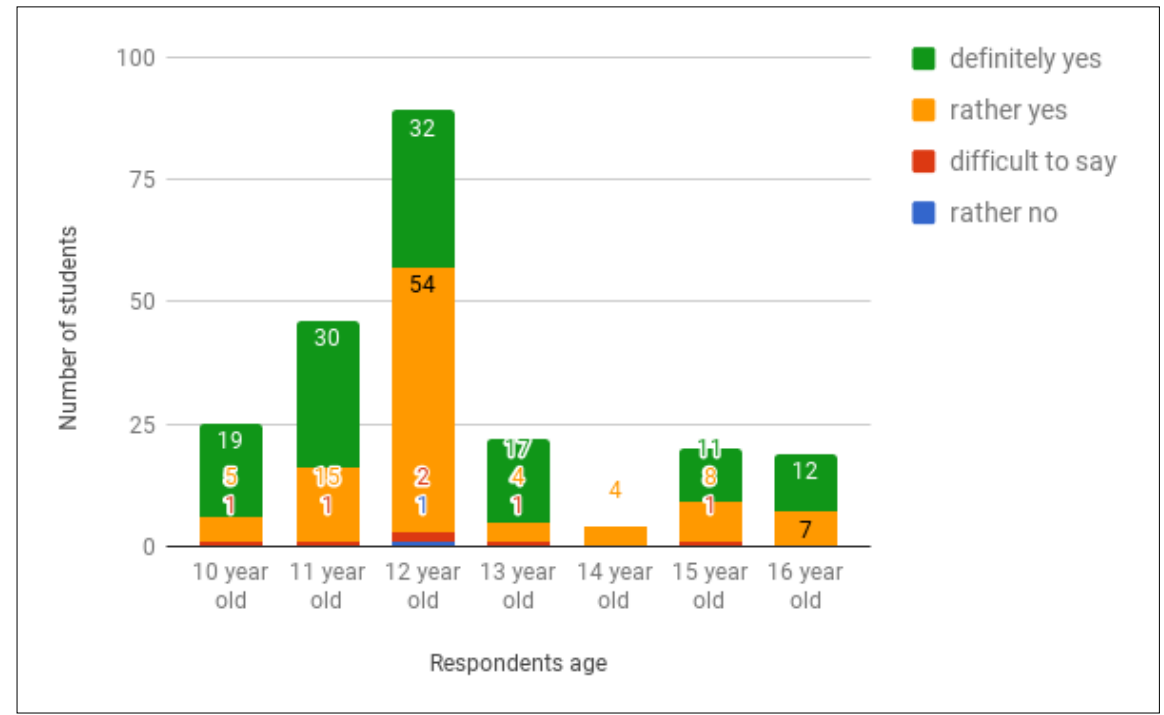

Chart 2. Summary of opinions of studied students by age on the possibility of learning new and valuable information in non-formal education

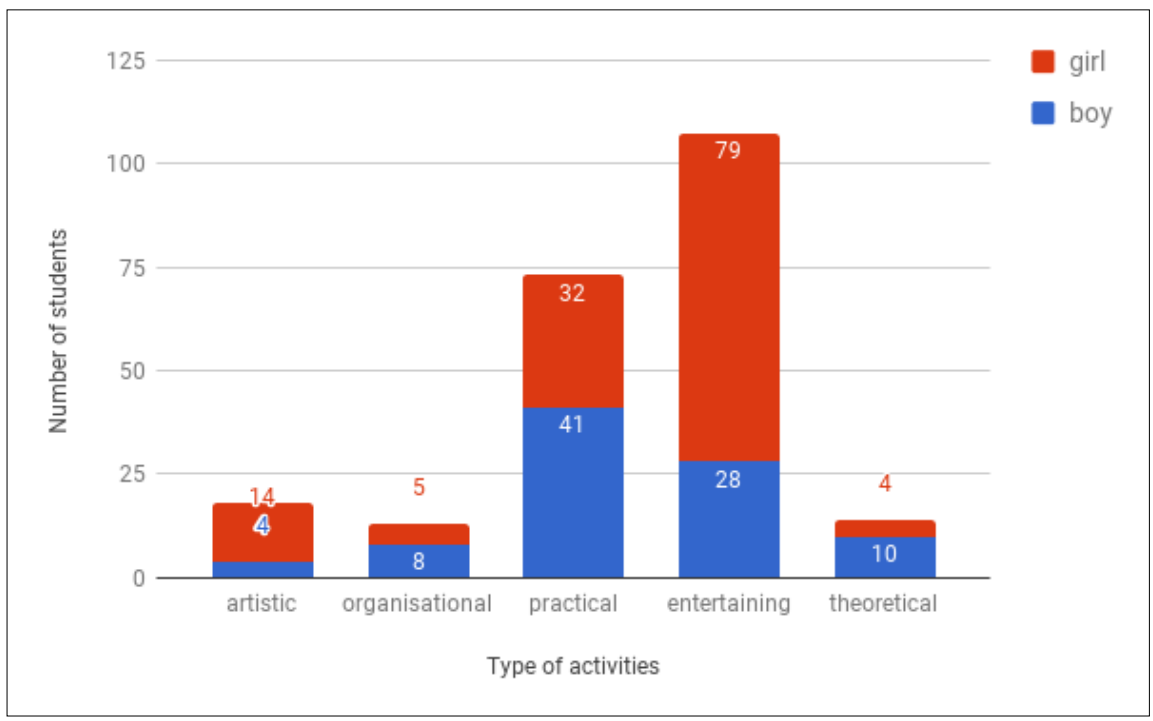

Chart 3. Test results of determination the directions of development of non-formal education by surveyed students' gender 
Analysing the results of the research, we can conclude that a large group of studied girls focused their expectations on entertaining and practical-productive activities, while the largest part of boys chose practical-productive classes. These results confirm the growing need for an increased number of practical courses in schools. Students prefer practice and action over theoretical classes, as shown in the attached diagram.

The second aim of the study was to investigate the significance of interactive workshops and their relationship with non-formal education. When it comes to the definition of interactive workshops, students defined them differently. Frequent answers allow for interpreting interactive workshops as: form of classes which uses a lot of modern educational technology and they are very useful, because they involve cooperation and discussion, and thus gaining new knowledge also from peers.

Respondents also expressed their opinions regarding the belonging of interactive workshops to non-formal education.

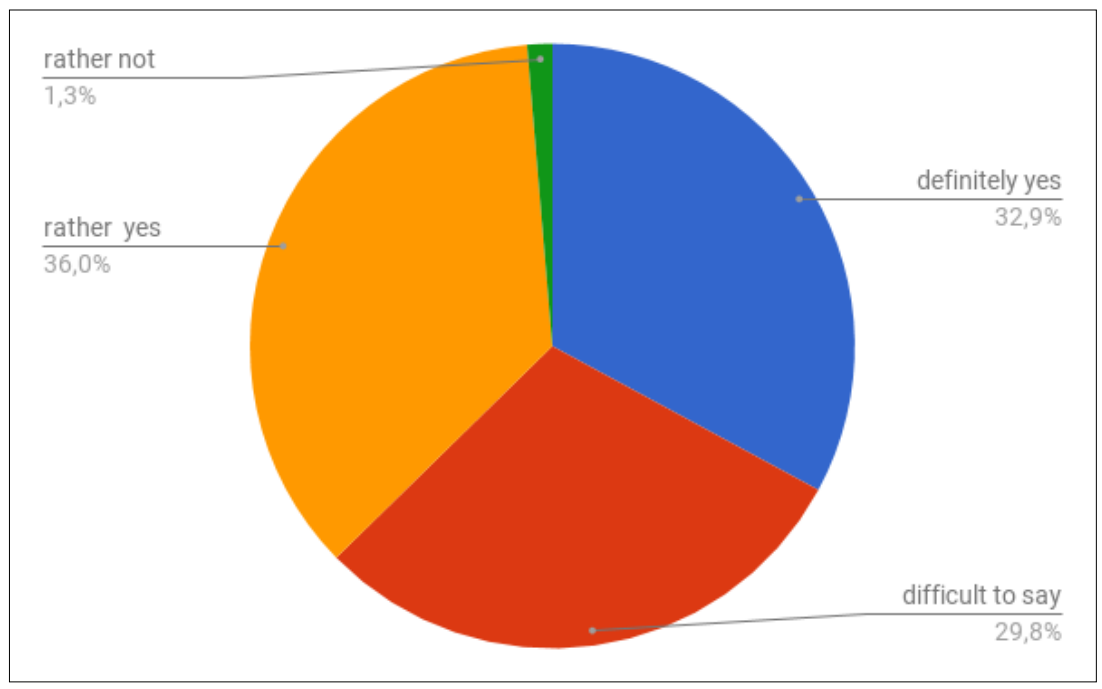

Chart 4. Summary of results of the students' opinion on the interactive workshop belonging to non-formal education

The majority agreed that interactive workshops are a type of non-formal education. In the studied group, $29.8 \%$ of respondents stated that they are not 
able to determine whether this type of interactive workshops is a type of nonformal education and $1.3 \%$ claimed that it is rather non-formal education. An interesting aspect of the activities carried out was, of course, the opinion on their usefulness. In the studied group, 75.1\% respondents claimed that thanks to the workshops conducted they acquired completely new knowledge, 19.6\% said that they rather acquired new information, the rest was not able to answer, saying that it is difficult to tell.

The last question in this regard concerned the willingness to re-participate in such activities. The results showed that $92.4 \%$ respondents expressed the readiness to participate in such workshops again, while others responded that it is difficult to tell. This result shows the need for the creation and organisation of such workshops for students.

The final plane of study are the effects obtained after a series of classes. The study was conducted within the framework of a single survey as a separate section (Internet 3).

The range for the effects of activities was carried out on the basis of verification of selected information. Students were asked to give the correct answer. In the case of the first question - "what ciphers were you familiarised with during the classes" - the results are presented below.

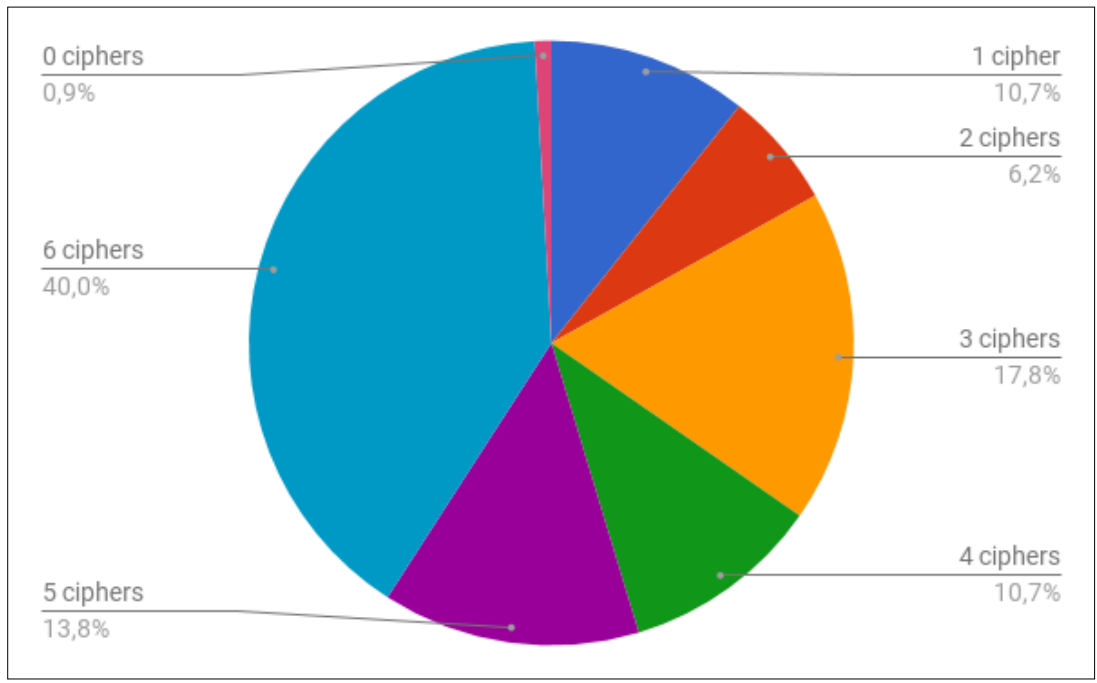

Chart 5. Summary of overall results on the number of memorised data cipher names 
In the conducted workshops, students learned about 6 types of ciphers, and $40 \%$ of respondents were able to specify their names at the end. This shows that almost half of them memorised all data ciphers. Given that $13.8 \%$ memorised 5 names of ciphers, it gives over half of the sample in total. Analysing the results, we can conclude that the effects achieved by the students in this field are very satisfactory. Analysing this question by gender is interesting, which is shown below.

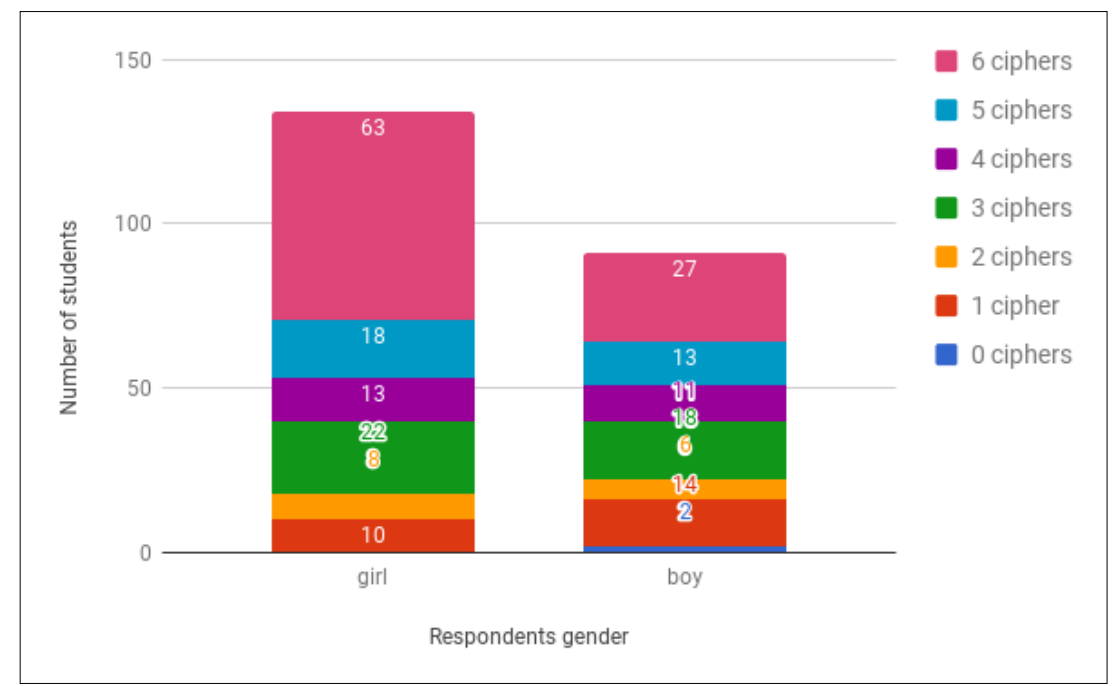

Chart 6. Summary of test results on the number of memorised cipher names by gender

The chart shows that girls memorised more cipher names than boys. We can conclude that girls might have been more attentive in classes, and that the young generation of women begins to displace the dominant role of men in the sciences (Internet 4).

In the next verifying question, respondents were asked about the number of metal plates in the German Enigma machine. The results of the survey question are very satisfactory, because as much as $91 \%$ gave the correct answer. The rest replied I do not know.

Another question was an open one, in which students had to describe the use of one of the ciphers. The question was evaluated based on the allocation of the value of "true" or "false". The results are again very satisfactory, $81 \%$ of 
respondents gave the correct answer to the question. Another summary of the results by gender shows that once again the answers granted by girls are "true" in $43 \%$ of cases and $27.8 \%$ in boys, while for the "false" results, the summary was almost identical - girls $10 \%$, boys $9 \%$.

In the study on the effects of activities, next question was also important, information on which was mentioned only once, and concerned the successor of the Caesar cipher. The question was directed mainly to test students' ability to focus. The survey results are satisfactory, because $57.8 \%$ of answers are correct, while, unfortunately, the remaining ones are negative. Data analysis by gender once again shows that girls gave more correct answers. In this question, $42 \%$ of girls answered correctly, and only $16 \%$ of boys did that.

Then, attention was focused on the practical operation, the conversion of the binary number to a decimal. The results were almost equally divided, because $50.2 \%$ calculated correctly the number and $49.8 \%$ did it wrong. When divided by gender, girls achieved better results $-37 \%$ made correct calculations and gave the correct number, while only $13 \%$ of boys managed to do so. It is another question, which shows that girls contributed to the activities significantly more or it is simply the result of changes that occur in their interests.

The last question was to verify the respondents' memory. They had to recreate the data encryption method using the Polybius algorithm. In this case, $64.4 \%$ gave the correct answer, the rest were wrong. Again, in this question, the results by gender have not changed. Girls memorised it better and had better practical skills, as $43.6 \%$ of them answered correctly, while only $20.9 \%$ of boys did. It is quite a surprise, because it is boys who should be more interested in this topic and, consequently, should memorise information better, but the result shows the opposite.

\section{Conclusions}

From the studies presented above, we can draw a fairly general conclusion that studies show non-formal education as an important element of the contemporary and future education. Of course, based on the results presented, we can also specify that the value of non-formal education for the modern student is enormous and it should be continued and more broadly introduced into traditional education. Obviously, we cannot forget about the basis of general education at a given level of education.

The plane, specified in study assumptions, concerning non-formal education, has been explained through answers to the questions, given by the re- 
spondents. One of the most important ones was the answer to the question concerning the definition of non-formal education according to the respondent's opinion. Research shows that students define this kind of education in a very similar way to definitions of non-formal education contained in the references, enlisting components of this kind of education. Based on the studies conducted, we can conclude that it is a kind of additional education classes, which feature the content other than in traditional classes, as it is enriched with various forms of work with students. Students' knowledge on the place of non-formal education is satisfactory, as $76.4 \%$ were able to name at least one place of non-formal education. According to the responses, we should also note that participation in the workshops allowed students to acquire new knowledge and skills that they could never acquire in school. 11 and 12-year olds gained the greatest benefits from the classes. In the study conducted, students also identified the most desirable development paths for this kind of education, where the direction of practical-productive classes is noteworthy along with the fact that not only boys, but girls as well want this direction to be developed.

Research in the field of interactive workshops showed that students see the correlation between the concepts of non-formal education and interactive workshops, as many as $68.9 \%$ described the conducted interactive workshops as a kind of non-formal education. The respondents expressed their opinions regarding new knowledge they have gained in the classes conducted. Approximately $75.1 \%$ of the respondents claimed that during these activities they learned things that were previously completely unknown to them. Successfully, as many as $92.4 \%$ of respondents expressed the desire to participate again in such activities, and the rest abstained.

The effects of these activities have been confirmed by the study, because as shown by the results above, a small proportion of students was not able to name a half of the known ciphers, and the greater part of the group enumerated all or all but one. The analysis in terms of gender also showed very interesting information. In most of these questions, both relating to the memorised information and the practical one, girls responded significantly better than boys. When it comes to efficiency results, in each of the questions, more than a half of the responses was correct. Therefore, the conclusion from a series of activities carried out is as follows: these activities produced very satisfactory results in terms of the acquisition of information, as well as practical skills. It can be concluded that it is worth organising such forms of education and support schools in teaching. 


\section{Summary}

The modern school is subordinated to objectives determined by the core curriculum, a document that regulates in detail the educational policy of the state. Thus, formal education should reach the set goals and fulfil them in the best possible way. However, the presented study results show that one should not forget about the role and value of non-formal education.

Support for the traditional process of formal education through non-formal education helps to fulfil other, additional goals. This kind of education provides new directions of development of formal education, mainly because students are able to participate in activities organised, e.g. at universities and other places where we can organise activities which are non-formal in nature (Sławiński, 2014, p. 13-21). This gives a number of benefits, e.g. related to a new place of learning that stimulates the interest of the student, and, as it is usually the case, the student's interests constitute at least a half of the educational success. Classes in non-formal education also allow for expanding students' knowledge and skills in different areas.

The studies conducted show that non-formal education is accepted and treated by students in a very friendly and positive way. Students participate in activities they are interested in willingly. This kind of education introduces something new, freshness, quality, efficiency. Formal education must consider the contemporary division of education and accept the need for education of non-formal and informal nature.

As the study results show, the activities carried out in the form of interactive workshops create additional cognitive opportunities for students thanks to technological support used in the implementation of activities. This was possible thanks to the technical means (laboratory) available at university, which are better than in school. Thanks to this, apart from the educational value, the student was able to work with new technologies, which, unfortunately, are not so popular in schools.

The attempt to assess the effects of the activities carried out provided satisfactory results. It can be argued that the above-mentioned new quality of nonformal education has met its objectives and thus achieved expected results. It is possible that in the future it will be one of the basic pillars supporting the traditional school system (formal education).

In conclusion, we should focus on a broader study of non-formal education in various aspects (advantages and disadvantages) and indicate the correct direction of the organisation of such activities to best meet the needs of students 
and teachers in terms of the content of implemented extracurricular activities. The organisation of such activities must be well thought and implemented in accordance with all guidelines posed against non-formal education.

\section{References}

Falk, J., Needham, M. (2013). Factors Contributing to Adult Knowledge of Science and Technology. Journal of Research in Science Teaching, 50, 4, pp. 431-452.

Falk, J., Dierking, L., Swanger, L., Staus, N., Back, M., Barriault, C., Catalao, C., Chambers, C., Chew, L., Dahl, S., Falla, S., Gorecki, B., Lau, T., Lloyd, A., Martin, J., Santer, J., Singer, S., Solli, A., Trepanier, G., Tyystjarvi, K., Verheyden, P. (2016). Correlating Science Center Use With Adult Science Literacy: An International, Cross-Institutional Study. Science Education, 100, 5, pp. 422-445.

Knowles, M., Holton, E. F., Swanson, R. (2009). Edukacja dorostych. Warszawa: Wydawnictwo Naukowe PWN.

Kupisiewicz, Cz. (2012). Dydaktyka. Kraków: Oficyna Wydawnicza „Impuls”.

Kurzępa, J. (2004). O potrzebie komplementarności w edukacji formalnej i nieformalnej: aplikacje teoretyczno-praktyczne. Doświadczać uczenia. Warszawa: Fundacja Rozwoju Systemu Edukacji.

La Belle, T. (1982). Formal, nonformal and informal education: A holistic perspective on lifelong learning. International Review of Education, 28, 2, pp. 159-175.

Latchem, C. (2014). Informal Learning and Non-Formal Education for Development. Journal of Learning for Development, 1, 1, pp. 235-256.

Rogers, A. (2005). Non-formal Education, Flexible Schooling or Participatory Education? Hong Kong: Springer Science + Business Media Inc.

Sławiński, S., Dębowski, H., Michałowicz, H., Urbanik, J. (2014). Słownik podstawowych terminów dotyczacych krajowego systemu kwalifikacji. Warszawa: Instytut Badań Edukacyjnych.

Souto-Otero, M., Ulicna, D., Schaepkens, L., Bognar, V. (2012). Study on the impact of Non-Formal Education in youth organisations on young people's employability. Commissioned by the European Youth Forum Authored by Bath University/GHK Consulting.

Stalończyk, I. (2014). Edukacja formalna i pozaformalna w procesie kształtowania społeczeństwa wiedzy. Nierówności Społeczne a Wzrost Gospodarczy, 37, pp. 320-332.

Tabor, J. (2014). Place of non-formal education in the career building process. Polish Journal of Management Studies, 9, pp. 233-243. 
Walat, W. (2007). Edukacyjne zastosowania hipermediów. Rzeszów: Wydawnictwo Uniwersytetu Rzeszowskiego.

Warchoł, T. (2017). Support for formal education with the use of non-formal education interactive workshops. Edukacja - Technika - Informatyka, 2(20), pp. 46-50, DOI: 10.15584/eti.2017.2.5.

Internet 1: https://men.gov.pl/ministerstwo/informacje/ustawy-wprowadzajace-reformeedukacji-opublikowane-w-dzienniku-ustaw.html [access: 2017-07-14].

Internet 2: http://www.mlodziez.com.pl/pfe/?slowniczek,2 [access: 13.07.2017].

Internet 3: Survey: https://goo.gl/forms/MCHY710V2HZ9AFOl2 [access: 16.07.2017].

Internet 4: http://www.bezuprzedzen.org/doc/ksztalcenie_matematyki_plec.pdf [access: 19.07.2017]. 